\title{
GROUND NESTING BY AECHMOPHORUS GREBES IN ORANGE COUNTY, CALIFORNIA
}

GARY M. SANTOLO, Jacobs, 2485 Natomas Park Drive, Suite 600, Sacramento, California 95833; gary.santolo@jacobs.com

Nesting by grebes of any species on a solid nonfloating surface, such as the ground, rocks, or a concrete structure, is very rare and has been reported in only five species: the Least Grebe (Tachybaptus dominicus; Hayes 2018), Great Crested Grebe (Podiceps cristatus; Simmons 1955, Ulfvens 1988), Horned Grebe (Podiceps auritus; Fjeldså 1973), and Western Grebe (Aechmophorus occidentalis) and Clark's Grebe (A. clarkii; Nero et al. 1958, Nero 1959). In the latter two species such nests are considered rare (Riensche et al. 2009, LaPorte et al. 2013). For example, Hayes et al. (pers. comm.) observed no active nests on land during a ten-year study of 32,234 nests of the Western and Clark's Grebes at Clear Lake, Lake County, California, although a few with abandoned eggs were stranded by receding water levels. Here I report on Aechmophorus grebes nesting on the ground in a wetland in southern California.

Western and Clark's grebes and their hybrids nest along San Diego Creek at the Irvine Ranch Water District's San Joaquin Marsh and Wildlife Sanctuary, Irvine, California. The sanctuary includes over 121 hectares of constructed coastal freshwater wetlands above the creek's outlet to upper Newport Bay. These ponds are used to clean urban runoff, and these grebe species have been identified in Sea and Sage Audubon's regular surveys of the ponds since 2004. Since 2014 the number of grebes using the ponds has been increasing, especially during the breeding season from April through June (https://www.seaandsageaudubon.org/BirdInfo/BirdCounts/ SJWScensus/SJWScensus.htm). The ponds' turbid waters are surrounded by cattails (Typha sp.) and bulrush (Schoenoplectus sp.). Fish species found in the ponds include the bluegill (Lepomis macrochirus), common carp (Cyprinus carpio), fathead

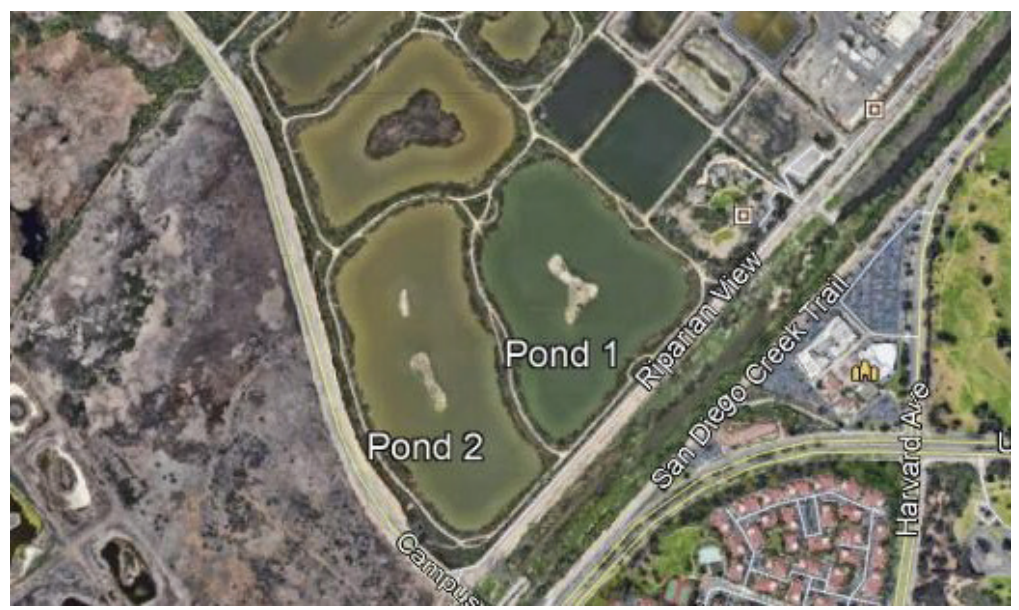

Figure 1. Ponds 1 and 2 of the Irvine Ranch Water District's San Joaquin Marsh and Wildlife Sanctuary along San Diego Creek, Orange County, California. 
minnow (Pimephales promelas), green sunfish (Lepomis cyanellus), largemouth bass (Micropterus salmoides), mosquitofish (Gambusia affinis), inland silversides (Menidia beryllina), red shiner (Notropis lutrensis), and threadfin shad (Dorosoma petenense), none of which is native to the area. From at least 2013, when their nesting was first observed, through 2017, grebes nested from late June to early July and the only nests found were the typical floating nests. In 2018, I observed the first ground nest in early June.

From 2004 to 2020 I surveyed bird nests as part of biological monitoring in the Newport Bay watershed that included sampling fish and bird eggs (Santolo et al. 2016). This effort included monitoring in two ponds at San Joaquin Marsh (ponds 1 and 2; Figure 1). Searches for nests of the Pied-billed (Podilymbus podiceps) and Aechmophorus grebes, American Coot (Fulica americana), Black-necked Stilt (Himantopus mexicanus), American Avocet (Recurvirostra americana), Killdeer (Charadrius vociferus), Forster's Tern (Sterna forsteri), and Black Skimmer (Rynchops niger) took place every other week from about 1 May to 1 July each year; for each species, searches were discontinued after eight nests with two or more eggs were found. Waterfowl and shorebird nests were found on the island in Pond 2 in all years except 2016, when only Canada Goose (Branta canadensis) nests were observed; however, no nests of any species were found on the island in Pond 1 until 2016, when three Black-necked Stilt nests were found and Caspian Terns (Hydroprogne caspia) also began nesting on the island. Since 2016, the numbers of species and nests on the Pond 1 island have increased. I had observed Aechmophorus grebes incubating in typical floating nests attached to the water-side edges of cattails and bulrush surrounding the ponds in the years I had been monitoring, but on 4 June 2018, I observed an Aechmophorus grebe nest with three eggs on the shore of the island in Pond 1. In 2019 , I found five ground and three floating nests, and in 2020, five ground and two floating nests. All nests were photographed, and examples of the ground nests are shown in Figure 2. These active nests were all located about 1.0-3.0 m from the water's edge, and I was able to observe various nests under construction, nests where additional eggs were laid after the nest was found, and, on occasion, incubation by a parent (Figure 3). Before 2018, when the first ground nest was found, Aechmophorus grebe nests were not observed until late June or early July.

I collected a single egg from each nest (up to eight eggs total per year; no egg was collected from the ground nest found in 2018) and measured the eggs as described by Santolo (2018). There were no significant differences in morphometrics between the eggs from the ground and floating nests (Table 1; unpaired $t$-test). All of the eggs collected were viable, and their incubation ages and the embryos' developmental stages (based on Hamilton 1952, Pisenti et al. 2001), at the time they were collected, ranged from day 0 , stage 3 (recently laid) to day 26, stage 45 (near hatching) for floating nests and from day 0 , stage 3 to day 9 , stage 32 for ground nests. I did not monitor nests for success.

From 2018 to 2020, Aechmophorus grebe nests were initiated earlier in the season than had been typical for these species at this location, and all of the earliest nests were ground nests. However, the timing of breeding is not remarkable, as in southern California Western Grebes may nest as early as January (Lee 1967), and in San Diego County breeding extends through most of the year (Unitt 2004). Although there appears to be adequate vegetation around the perimeter of the ponds early in the season, grebes may choose to nest on the ground early in the season at this site because of water management that changes the water levels in the ponds, although no signs of inundation or stranding of nests were observed. Further studies would be needed to determine factors influencing the timing of breeding.

Thanks to Jian Peng and Stuart Goong for support under county of Orange contract number MA-080-16011719, Ian Swift of Irvine Ranch Water District and Sea 
TABLE 1 Sizes of Clutches and Characteristics of Eggs in Floating and Ground Nests of Aechmophorus Grebes at the San Joaquin Marsh, Orange County, California

\begin{tabular}{|c|c|c|c|c|c|c|c|c|}
\hline \multirow[b]{2}{*}{ Variable } & \multicolumn{3}{|c|}{$\begin{array}{l}\text { Floating nests } \\
\qquad(n=5)\end{array}$} & \multicolumn{3}{|c|}{$\begin{array}{l}\text { Ground nests } \\
\quad(n=10)\end{array}$} & & \multirow[b]{2}{*}{$P$} \\
\hline & Mean & SD & Range & Mean & SD & Range & & \\
\hline Clutch size & 3.6 & 0.55 & $3-4$ & 3.3 & 0.67 & $2-4$ & 0.858 & 0.407 \\
\hline Mass (g) & 43 & 2.2 & $40-46$ & 44 & 2.8 & $38-48$ & 0.739 & 0.473 \\
\hline Length (mm) & 57 & 1.9 & $55-60$ & 57 & 1.6 & $55-60$ & 0.021 & 0.984 \\
\hline Width (mm) & 38 & 0.91 & $37-40$ & 38 & 1.0 & $37-40$ & 0.127 & 0.901 \\
\hline Volume $(\mathrm{mL})^{a}$ & 42 & 1.8 & $40-45$ & 42 & 2.1 & $39-45$ & 0.125 & 0.903 \\
\hline Density $\left(\mathrm{g} / \mathrm{cm}^{3}\right)^{a}$ & 1.0 & 0.05 & $0.95-1.1$ & 1.0 & 0.03 & $0.99-1.1$ & 1.35 & 0.199 \\
\hline Shell thickness $(\mathrm{mm})^{b}$ & 0.34 & 0.02 & $0.32-0.36$ & 0.33 & 0.04 & $0.26-0.37$ & 0.306 & 0.764 \\
\hline
\end{tabular}

${ }^{a}$ By the methods of Hoyt (1979).

${ }^{b}$ By the method of Santolo (2018).

and Sage Audubon staff for access, Harry Ohlendorf for an early review, and Floyd Hayes for his helpful comments and edits, which greatly improved the manuscript.

\section{LITERATURE CITED}

Fjeldså, J. 1973. Territory and the regulation of population density and recruitment in the Horned Grebe Podiceps auritus arcticus Boje, 1822. Vidensk. Meddel. Dansk Naturhist. Foren. 136:117-189.

Hamilton, H. L. 1952. Lillie's Development of the Chick. Holt, New York.

Hayes, F. E. 2018. Least Grebes (Tachybaptus dominicus) nesting on a nonfloating concrete structure at Roatán, Honduras. Waterbirds 41:183-185; doi. org/10.1675/063.041.0211.

Hoyt, D. F. 1979. Practical methods of estimating volume and fresh weight of bird eggs. Auk 96: 73-77; doi.org/10.1093/auk/96.1.73.

LaPorte, N., Storer, R. W., and Nuechterlein, G. L. 2013. Western Grebe (Aechmophorus occidentalis), in The Birds of North America (A. F. Poole, ed.), no. 26a, version 2.0. Cornell Lab Ornithol., Ithaca, NY; doi.org/10.2173/bow/wesgre.01.

Lee, D. T. 1967. Winter breeding of the Western Grebe. Condor 69:209-209; doi. org/10.2307/1366612.

Nero, R. W. 1959. Western Grebe colony. Nat. Hist. 68:291-295.

Nero, R. W., Lahrman, F. W., and Bard, F. G. 1958. Dry-land nest-site of a Western Grebe colony. Auk 75:347-349; doi.org/10.2307/4081980.

Pisenti, J. M., Santolo, G. M., Yamamoto, J. T., and Morzenti, A. A. 2001. Embryonic development of the American Kestrel (Falco sparverius): External criteria for staging. J. Raptor Res. 35:194-206.

Riensche, D. L., Mena, J. D., and Shawen, A. B. 2009. Western and Clark's grebe nest platforms designed for fluctuating water levels. Trans. W. Sect. Wildlife Soc. 45:7-16.

Santolo, G. M. 2018. A new nondestructive method for measuring eggshell thickness using a nonferrous material thickness gauge. Wilson J. Ornithol. 130:502-509; doi.org/10.1676/17-035.1.

Santolo, G. M., Byron, E. R., and Ohlendorf, H. M. 2016. Contaminants in sediment, food-chain biota, and bird eggs from the Newport Bay watershed, Orange County, California. Environ. Monit. Assess. 188:113-131. 


\section{NOTES}
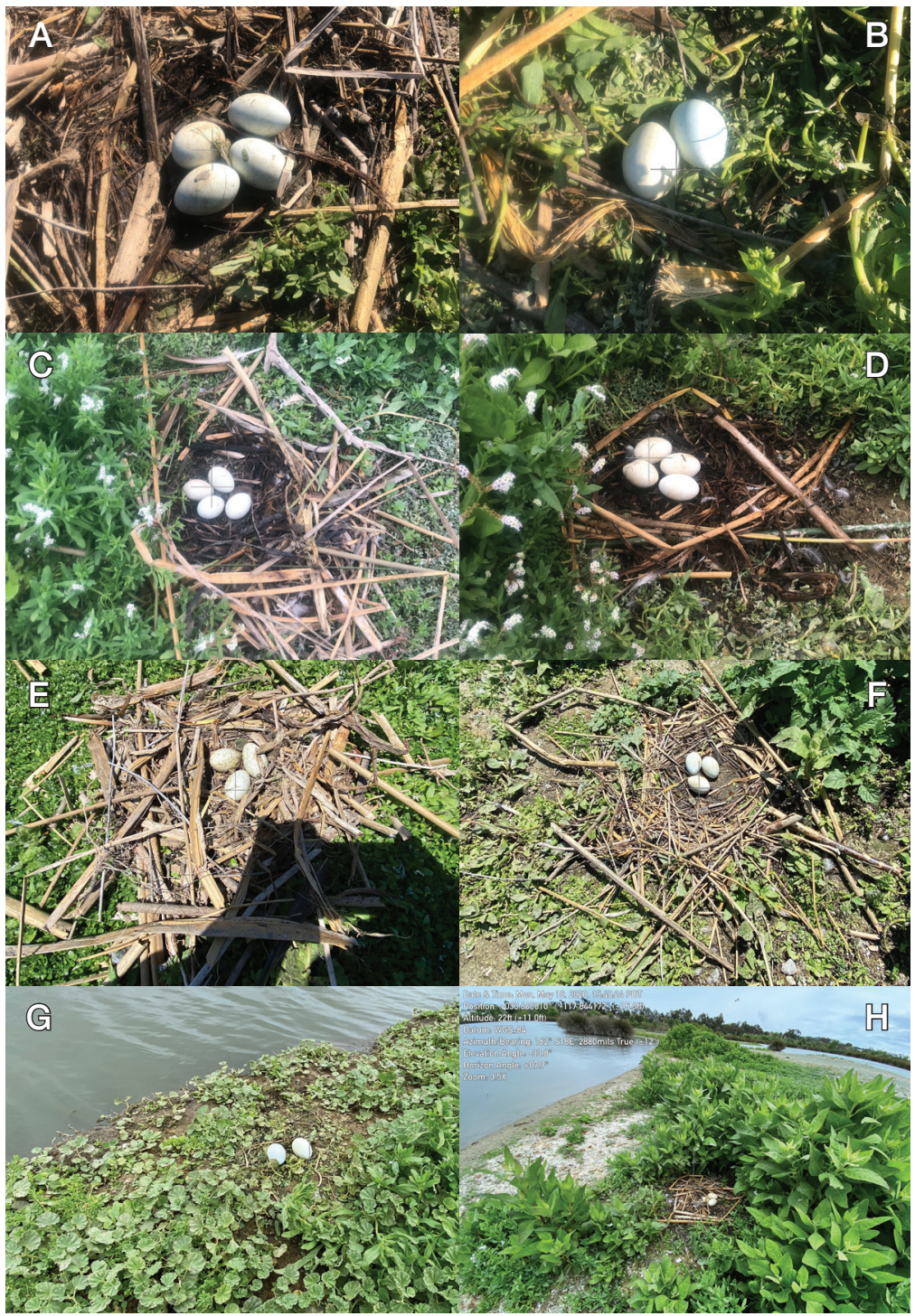

Figure 2. Selected Aechmophorus grebe ground nests found at the San Joaquin Marsh. (A) 17 May 2019, Pond 1; (B) 17 May 2019, Pond 1; (C) 3 June 2019, Pond 1; (D) 3 June 2019, Pond 1; (E) 4 May 2020, Pond 2; (F) 4 May 2020, Pond 1; (G) 18 May 2020, Pond 2; (H) 18 May 2020, Pond 2. 


\section{NOTES}

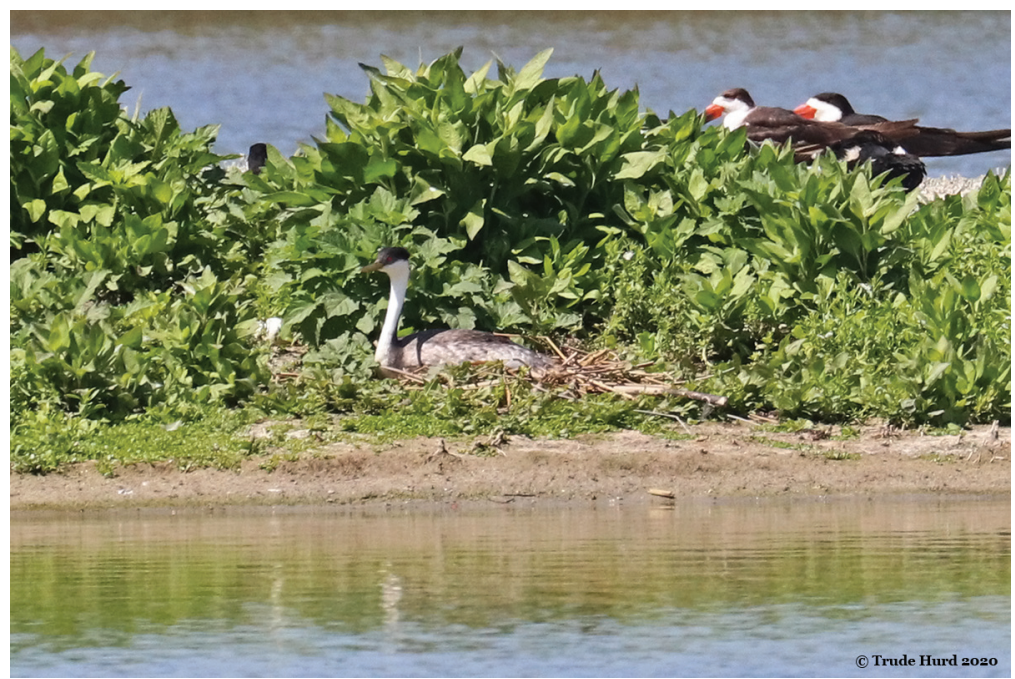

Figure 3. Western Grebe nesting on the island of Pond 1 at the San Joaquin Wildlife Sanctuary in Irvine, California, in May 2020.

Photo by Trude Hurd

Simmons, K. E. L. 1955. Studies on Great Crested Grebes. Avicult. Mag. 61:3-316.

Ulfvens, J. 1988. Comparative breeding ecology of the Horned Grebe Podiceps auritus and the Great Crested Grebe Podiceps cristatus: Archipelago versus lake habitats. Acta Zool. Fennica 183:1-75.

Unitt, P. 2004. San Diego County bird atlas. Proc. San Diego Soc. Nat. Hist. 39.

Accepted 22 March 2021 